\title{
Human Thrombomodulin Is Not an Efficient Inhibitor of the Procoagulant Activity of Thrombin
}

\author{
Ikuro Maruyama, Hatem H. Salem, Hidemi Ishii, and Philip W. Majerus \\ Division of Hematology-Oncology, Departments of Internal Medicine and Biological Chemistry, \\ Washington University School of Medicine, St. Louis, Missouri 63110
}

\begin{abstract}
The effect of human thrombomodulin isolated from placenta on the procoagulant activity of thrombin was studied and compared to that of rabbit thrombomodulin. The isolated protein was proved to be thrombomodulin because a rabbit antibody against the isolated protein blocked protein $\mathrm{C}$ activation by thrombomodulin in solution and also blocked the proteinC-activating cofactor activity of human umbilical vein endothelial cells. The affinity of human thrombomodulin for human thrombin in the presence of fibrinogen is $\mathbf{3 0}$ times less than that of rabbit thrombomodulin. This value is based on the measurements of the clotting time of human fibrinogen and thrombin in the presence of increasing amounts of thrombomodulin. Human thrombomodulin was also much less effective compared with rabbit thrombomodulin in inhibiting thrombininduced human coagulation factor $\mathrm{V}$ activation. The ability to inhibit release of $\left[{ }^{3} \mathrm{H}\right]$ serotonin from washed human platelets was at least 10 times less using human thrombomodulin compared with rabbit thrombomodulin. A partially purified preparation of human lung thrombomodulin was also relatively ineffective in inhibiting thrombin-induced serotonin release from platelets, indicating that the difference between rabbit and human thrombomodulin is one of species rather than of tissue. Thus, while human thrombomodulin is a potent cofactor in protein $\mathbf{C}$ activation, it is not an efficient inhibitor of the procoagulant actions of thrombin.
\end{abstract}

\section{Introduction}

Thrombomodulin is an endothelial cofactor, first isolated from rabbit lung, that has been shown to stimulate thrombininduced protein $\mathrm{C}$ activation by $>1000$-fold $(1,2)$. Activated protein $\mathrm{C}$ functions as a potent natural anticoagulant by inactivating coagulation Factors Va and VIIIa (3-5). Thus, thrombomodulin functions to convert thrombin from a procoagulant protease to an anticoagulant. This function is further emphasized by the finding that rabbit thrombomodulin also blocks the catalysis of a number of procoagulant reactions by thrombin including the following: 1) the clotting of fibrinogen $(6) ; 2)$ the activation of Factor V (6); and 3) the platelet release reaction (7). We have recently isolated the human form of thrombomodulin from placenta and have found that the protein is similar to rabbit thrombomodulin in many respects

Address correspondence to Dr. Majerus.

Received for publication 16 July 1984 and in revised form 7 November 1984.

J. Clin. Invest.

(c) The American Society for Clinical Investigation, Inc.

0021-9738/85/03/987/05 \$1.00

Volume 75, March 1985, 987-991
(8). The human protein also stimulates protein $\mathrm{C}$ activation by thrombin in a calcium-dependent reaction. Maximal rates of protein $\mathrm{C}$ activation are achieved at $\sim 1$ mol thrombomodulin/mol of thrombin, suggesting a 1:1 stoichiometric complex as reported for the rabbit protein. The apparent molecular weight of human thrombomodulin is 105,000 as determined in SDS polyacrylamide gels containing 2-mercaptoethanol and 75,000 in gels run without mercaptoethanol. These molecular weights are similar to those obtained with the rabbit protein. In addition, the two proteins have similar amino acid compositions, and antibodies against rabbit thrombomodulin inhibit human thrombomodulin in part $(8,9)$. We have found that the proteins of the two species differ in that the human protein is stimulated two- to three-fold by coagulation factor $\mathrm{Va}$, while the rabbit protein is not (8-10).

In this report we have compared the ability of thrombomodulin from the two species to inhibit thrombin-catalyzed procoagulant reactions, as well as the ability of rabbit antihuman thrombomodulin antiserum to inhibit protein $\mathrm{C}$ activation by each protein in solution and by cultured human umbilical vein endothelial cells.

\section{Methods}

Materials. Except where indicated, all reagents were purchased from Sigma Chemical Co., St. Louis, MO. Human Factor V (11), human (12), bovine thrombin (13), and human and bovine fibrinogen (14) were isolated as previously reported. Human thrombomodulin was isolated from placenta (8), and rabbit thrombomodulin from lung was provided by Drs. N. L. and C. T. Esmon. $\left[{ }^{3} \mathrm{H}\right]$ Serotonin was purchased from Amersham Corp., Arlington Heights, IL. Nitrocellulose sheets were purchased from Bio-Rad Laboratories, Richmond, CA.

Coagulation assays. All assays were done at $37^{\circ} \mathrm{C}$ using a Fibrometer (Becton Dickinson). Thrombin activity was determined as described previously (12), with the following modifications. A $200 \mu \mathrm{l}$ mixture of $5 \mathrm{nM}$ thrombin and increasing amounts of thrombomodulin were incubated in polypropylene cups at $37^{\circ} \mathrm{C}$. After $3 \mathrm{~min}$ incubation, 50 $\mu \mathrm{l}$ of $3 \mathrm{mg} / \mathrm{ml}$ fibrinogen was directly added in each cup, and the clotting time was measured. Factor $\mathrm{V}$ coagulation activity was measured in a one-stage assay using purified coagulation factors (14). $5 \mathrm{nM}$ human thrombin was incubated in increasing amounts of human or rabbit thrombomodulin for $3 \mathrm{~min}$ at room temperature, and $10 \mu \mathrm{l}$ of this mixture was added to $10 \mu \mathrm{l}$ of human Factor $\mathrm{V}(10 \mathrm{U} / \mathrm{ml})$. At the indicated times, samples were diluted and immediately assayed for Factor $\mathrm{V}$ activity.

Platelet preparation and measurement of $\left[{ }^{3} \mathrm{H}\right]$ serotonin release. The preparation of washed human platelets labeled with $\left[{ }^{3} \mathrm{H}\right]$ serotonin $(3$ $\mu \mathrm{Ci} / 1.5 \times 10^{9}$ platelets), and the measurement of serotonin release were carried out as previously described (15), with the following modification. A buffer of $0.14 \mathrm{M}$ sodium cacodylate (dimethylarsenate) containing $0.015 \mathrm{M}$ Tris- $\mathrm{HCl}, \mathrm{pH} 7.4,55 \mathrm{mM}$ glucose, and $5 \mathrm{mg} / \mathrm{ml}$ bovine serum albumin (BSA) was used with the $\left[{ }^{3} \mathrm{H}\right]$ serotonin-labeled platelet suspensions (16). Samples, $200 \mu \mathrm{l}$, of mixtures of various amounts of thrombomodulin and thrombin $(0.1 \mathrm{nM})$ were added to $300 \mu \mathrm{l}$ of platelet suspension and incubated for $3 \mathrm{~min}$ at room 
temperature. The reaction mixtures were then layered onto $0.3 \mathrm{ml}$ of an oil mixture (1 part Apiezon, 9 parts $n$-butylphthalate) in Eppendorf microfuge tubes and centrifuged at $12,000 \mathrm{~g}$ in a microcentrifuge (Brinkmann Instruments, Inc., Westbury, NY) for 5 min. Radioactivity in the supernatant solution was measured in a liquid scintillation counter (model LS 6800, Beckman Instruments, Inc., Fullerton, CA). The same experiment was performed with thrombomodulin partially purified from human lung. The results are expressed as the percent of serotonin released.

Inhibition of human or rabbit thrombomodulin by anti-human thrombomodulin IgG. Polyclonal anti-human thrombomodulin antibody was prepared using human thrombomodulin as the antigen. Antithrombomodulin $\mathrm{IgG}$ was isolated from immunized rabbit serum using protein A Sepharose and was monospecific as determined by Western blots (8). Human or rabbit thrombomodulin, $0.05 \mathrm{pmol}$, was incubated with 0-10 $\mu$ g anti-human thrombomodulin IgG for $15 \mathrm{~min}$ at $37^{\circ} \mathrm{C}$, and then cofactor activity of the thrombomodulin was assayed in reaction mixtures containing protein $\mathrm{C}, 1.0 \mu \mathrm{M}$, and thrombin, 40 $\mathrm{nM}$, in a total volume of $30 \mu \mathrm{l}$ containing $20 \mathrm{mM}$ Tris $\mathrm{HCl}, \mathrm{pH} 7.4$, $0.15 \mathrm{M} \mathrm{NaCl}, 1 \mathrm{mM} \mathrm{CaCl}$, and $5 \mathrm{mg} / \mathrm{ml} \mathrm{BSA}$. Protein $\mathrm{C}$ activation was terminated by addition of $40 \mathrm{U} / \mathrm{ml}$ hirudin and $350 \mu \mathrm{g} / \mathrm{ml}$ antithrombin III. The amount of protein Ca formed was assayed by measuring the rate of hydrolysis of D-Phe-pipecolyl-Arg- $\rho$-nitroanilide (S2238; Kabi Diagnostica, Sweden) at $25^{\circ} \mathrm{C}$. Reaction mixtures contained $0.2 \mathrm{mM} \mathrm{S} 2238$ in $20 \mathrm{mM}$ Tris, $\mathrm{pH} 7.4,0.1 \mathrm{M} \mathrm{NaCl}$, and 5 $\mathrm{mg} / \mathrm{ml} \mathrm{BSA}$ as described previously (10).

The effect of anti-thrombomodulin antibodies on protein $\mathrm{C}$ activation was also studied using primary cultured endothelial cells. Human umbilical vein endothelial cells were cultured in 96-well (6 $\mathrm{mm}$ ) plates as previously described (9). The medium was removed from confluent monolayers of cells, and cells were washed three times with medium 199 (KC Biological Inc., Lenexa, KS). The cells were then incubated with $10 \mu \mathrm{g}$ of polyclonal anti-thrombomodulin IgG or control rabbit $\mathrm{IgG}$ in $40 \mu \mathrm{l}$ of medium 199 at $37^{\circ} \mathrm{C}$. After a 60 -min incubation, the medium was removed, and the cells were washed twice with buffer containing $0.015 \mathrm{M}$ Tris $\mathrm{HCl}, \mathrm{pH} 7.4,55 \mathrm{mM}$ glucose, 5 $\mathrm{mg} / \mathrm{ml} \mathrm{BSA}$, and $2.5 \mathrm{mM} \mathrm{CaCl}$. Reaction mixtures containing 0.5 $\mu \mathrm{M}$ protein $\mathrm{C}$, and $1 \mathrm{nM}$ thrombin in a final volume of $40 \mu \mathrm{l}$ of Tris albumin with $2.5 \mathrm{mM} \mathrm{CaCl}$ were added to the endothelial cells in wells. Incubations were carried out for $60 \mathrm{~min}$ at $37^{\circ} \mathrm{C}$, after which reactions were terminated by addition of hirudin and anti-thrombin III. Protein $\mathrm{Ca}$ formed in the reaction mixtures was assayed using benzoyl arginine ethyl ester (9).

Purification of human lung thrombomodulin. Human lung $(7 \mathrm{~g})$ obtained at autopsy from a 30 -yr-old man who died in an accident was frozen within $6 \mathrm{~h}$ of death. The sample was shredded using a vegetable shredder and homogenized in $70 \mathrm{ml}$ of $\angle 0 \mathrm{mM}$ Tris buffer, pH 7.4, containing $0.15 \mathrm{M} \mathrm{NaCl}, 0.2 \%$ nonidet $\mathrm{P}-40,0.02 \%$ sodium azide, $2 \mathrm{mM}$ diisopropylfluorophosphate, $1 \mathrm{mM}$ EDTA, and $10 \mathrm{mM}$ benzamidine using a Polytron tissue homogenizer (Kinematica $\mathrm{GmbH}$, Switzerland). The thrombomodulin was extracted by stirring for $4 \mathrm{~h}$ at $4^{\circ}$. The solubilized preparation was then dialyzed against 8 liters of

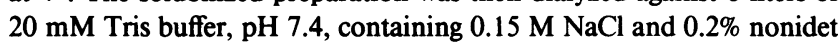
$\mathrm{P}-40$ for $2.5 \mathrm{~h}$. The sample was then applied to a $2-\mathrm{ml}$ column of rabbit antithrombomodulin Sepharose at a flow rate of $6 \mathrm{ml} / \mathrm{h}$. The immunoaffinity column was prepared by coupling $15 \mathrm{mg}$ of polyclonal anti-thrombomodulin IgG to Sepharose 4B by the method of Wallace et al. (17). The column was washed with $100 \mathrm{ml}$ of the same buffer and then with $50 \mathrm{ml}$ of the same buffer containing $0.5 \mathrm{M} \mathrm{NaCl}$. Thrombomodulin was subsequently eluted using $0.2 \mathrm{M}$ glycine, $\mathrm{pH} 3$, containing $0.2 \%$ nonidet $\mathrm{P}-40$. Fractions $(0.5 \mathrm{ml})$ were collected into tubes containing $0.04 \mathrm{ml}$ of $1 \mathrm{M}$ Tris buffer, $\mathrm{pH} 10.8$, resulting in a final $\mathrm{pH}$ of 7.4. Thrombomodulin content of the eluate was estimated by measuring rates of protein $\mathrm{C}$ activation as described above. We assumed that the activity of human lung and placental thrombomodulin were the same, and, therefore, we used the measure of activity to calculate the concentration of lung thrombomodulin.

Immunoblot of lung thrombomodulin. SDS-polyacrylamide gel elec- trophoresis was performed by the method of Laemmli (18) using 4\% acrylamide in the stacking and $10 \%$ acrylamide in the running gel. Samples of placental thrombomodulin and the immunoaffinity-purified extract from human lung were electrophoresed with 2-mercaptoethanol. Immunoblotting was performed by the method of Burnette (19). Antithrombomodulin serum was used at a 1:250 dilution and detection was made using ${ }^{125} \mathrm{I}$ protein $\mathrm{A}$ and autoradiography.

\section{Results}

The effect of thrombomodulin on fibrinogen clotting activity of thrombin. The effect of thrombomodulin on thrombin's ability to clot fibrinogen was studied with combinations of human or bovine thrombin and fibrinogen. The thrombomodulin preparations used in these experiments had similar ability to stimulate protein $\mathrm{C}$ activation as indicated below. The thrombin concentration was held constant and clotting time was measured as a function of increasing thrombomodulin (Fig. 1). As rabbit thrombomodulin was increased, there was a rapid prolongation of the clotting time in all three experiments, using human or bovine fibrinogen with human or bovine thrombin. The inhibition of thrombin clotting activity by rabbit thrombomodulin was greatest using bovine thrombin with bovine fibrinogen. For example, a mixture of $5 \mathrm{nM}$ bovine thrombin with $8 \mathrm{nM}$ rabbit thrombomodulin does not clot bovine fibrinogen. As the human thrombomodulin concentration was increased, progressive prolongation of clotting time was observed. The inhibition by human thrombomodulin was most efficient using bovine thrombin in the presence of bovine fibrinogen. The relative ability of thrombomodulin in the presence of fibrinogen to inhibit thrombin in these experiments is summarized in Table I. Human thrombomodulin is $\sim 30$-fold less potent in inhibiting human thrombin and human fibrinogen than is rabbit thrombomodulin in the same system.

The effect of thrombomodulin on Factor $V$ activation by thrombin. We also studied the ability of thrombomodulin to inhibit thrombin-catalyzed Factor $\mathrm{V}$ activation. Human Factor $\mathrm{V}$ is activated $\sim 25$-fold by thrombin as measured by our coagulation assay (11). We incubated purified human Factor $\mathrm{V}$ with $5 \mathrm{nM}$ thrombin and an increasing amount of thrombomodulin and then monitored the Factor $\mathrm{V}$ coagulant activity. In the absence of thrombomodulin, the activity of Factor $\mathrm{V}$

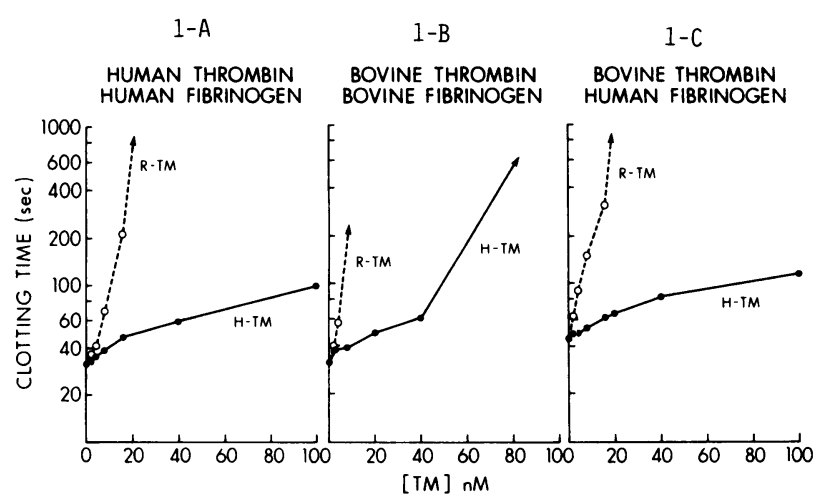

Figure 1. The effect of thrombomodulin on fibrinogen clotting activity of thrombin. The effect of thrombomodulin on thrombin's ability to clot fibrinogen was studied as described in Methods. A: human thrombin and fibrinogen; $B$ : bovine thrombin and fibrinogen; $C$ : bovine thrombin and human fibrinogen. Human thrombomodulin $(\mathrm{H}-\mathrm{TM})(\bullet)$, rabbit thrombomodulin (R-TM) (0). $(\rightarrow)$, did not clot in $1,000 \mathrm{~s}$. 
Table I. Apparent Affinity of Thrombin for Thrombomodulin in the Presence of Fibrinogen

\begin{tabular}{llll}
\hline & $\begin{array}{l}\text { Human thrombin } \\
+ \text { human } \\
\text { fibrinogen }\left(\mathrm{K}_{\text {spp }}\right)\end{array}$ & $\begin{array}{l}\text { Bovine thrombin } \\
+ \text { bovine } \\
\text { fibrinogen }\left(\mathrm{K}_{\text {spp }}\right)\end{array}$ & $\begin{array}{l}\text { Bovine thrombin } \\
+ \text { human } \\
\text { fibrinogen }\left(\mathrm{K}_{\text {spp }}\right)\end{array}$ \\
\hline & $n M$ & $n M$ & $n M$ \\
$\begin{array}{l}\text { Human } \\
\text { thrombomodulin }\end{array}$ & $79 \pm 27$ & $25 \pm 16$ & $38 \pm 7$ \\
$\begin{array}{l}\text { Rabbit } \\
\text { thrombomodulin }\end{array}$ & $2.5 \pm 1.3$ & 2.5 & $5.9 \pm 3.5$
\end{tabular}

The calculations in this table are based on the results of Fig. 1. The clotting times of the experiment were converted to thrombin units as described previously (10) in order to calculate free thrombin concentrations. The apparent dissociation constant was calculated from the equation $([\mathrm{T}][\mathrm{Tm}]) /([\mathrm{T} \cdot \mathrm{Tm}])=\mathrm{K}_{\mathrm{app}}$. We assumed that thrombin (T) and thrombomodulin (Tm) form a 1:1 complex in these calculations. The results are calculated at each thrombomodulin concentration (mean $\pm \mathrm{SD}$ ). These apparent dissociation constants probably do not equal the true dissociation constant of thrombin for thrombomodulin since the reaction is affected by fibrinogen. They do, however, serve to illustrate the difference between protein from the two species.

increased 23-fold in $10 \mathrm{~min}$. In the presence of rabbit thrombomodulin, the activation of Factor $\mathrm{V}$ was significantly inhibited (Fig. 2). After a 10-min incubation, the increase of Factor $\mathrm{V}$ coagulant activity was sevenfold with $20 \mathrm{nM}$ rabbit thrombomodulin and threefold with $200 \mathrm{nM}$. In the presence of human thrombomodulin the inhibition of Factor $\mathrm{V}$ activation was minimal. Factor $\mathrm{V}$ coagulant activity increased 22.7-fold with $100 \mathrm{nM}$ human thrombomodulin and 19-fold with $350 \mathrm{nM}$ thrombomodulin (Fig. 2).

The inhibition of thrombin-induced $\left[{ }^{3} H\right]$ serotonin release from washed human platelets by thrombomodulin. An additional property of thrombin is to activate platelets by inducing aggregation and secretion. The effect of thrombomodulin on human thrombin-induced serotonin release from platelets was studied. In the absence of thrombomodulin, $80 \%$ of serotonin was released from platelets in cacodylate buffer (16) by 0.1 nM human thrombin (Fig. 3). Serotonin release was inhibited with increasing thrombomodulin concentration. It was de-

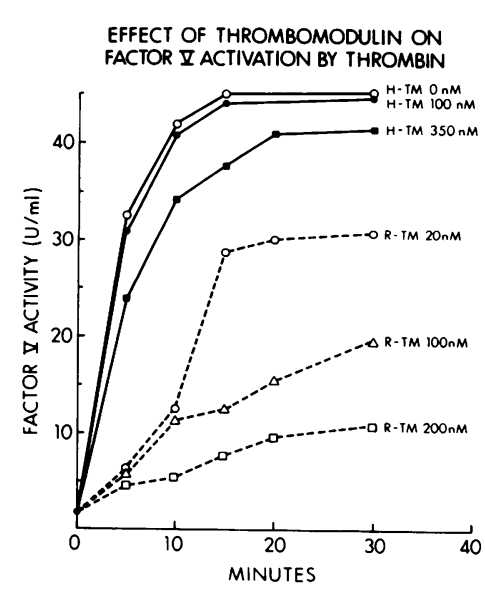

Figure 2. The effect of thrombomodulin on factor $\mathrm{V}$ activation by thrombin. $5 \mathrm{nM}$ of human thrombin were incubated with increasing amounts of human

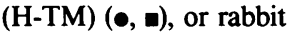
(R-TM) (o- - o, $\Delta, \square)$ thrombomodulin for $3 \mathrm{~min}$ at room temperature, and $10 \mu \mathrm{l}$ of each mixture was added to $10 \mu$ l of human Factor $\mathrm{V}(10 \mathrm{U} / \mathrm{ml})$. (o- o, no thrombomodulin.) At the indicated times, samples were taken and assayed for Factor $\mathbf{V}$ activity.

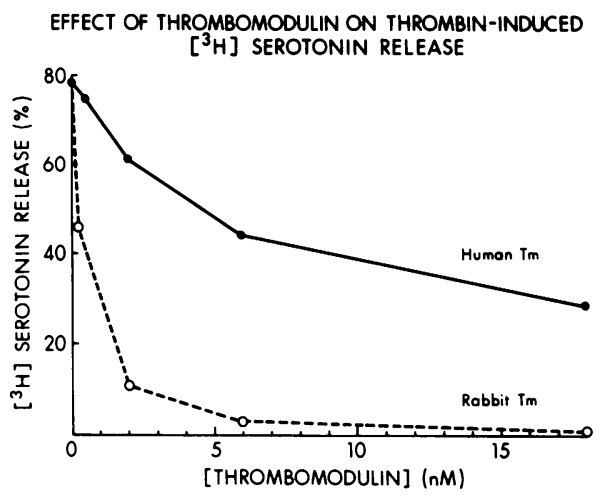

Figure 3. The inhibition of thrombin-induced $\left[{ }^{3} \mathrm{H}\right]$ serotonin release from human platelets. Thrombin $0.1 \mathrm{nM}$ was incubated for $3 \mathrm{~min}$ with the indicated concentrations of human (๑), or rabbit (o) thrombomodulin and then added to platelets containing $\left[{ }^{3} \mathrm{H}\right]$ serotonin. Serotonin release was measured as described in Methods.

creased $\sim 50 \%$ by the addition of $6 \mathrm{nM}$ human thrombomodulin. Rabbit thrombomodulin inhibited the release reaction more effectively; $50 \%$ inhibition occurred at $0.5 \mathrm{nM}$.

Effect of rabbit anti-human thrombomodulin on protein $C$ activation. IgG from a polyclonal antiserum that is monospecific for human thrombomodulin (8) was used to demonstrate antigenic differences between human and rabbit thrombomodulin and also to prove that the protein that we isolated accounts for the thrombomodulin activity previously found on human umbilical vein endothelium (1). Thrombomodulin from the two species stimulated protein $\mathrm{C}$ activation equally as shown in Fig. 4 and anti-thrombomodulin IgG inactivates human but not rabbit thrombomodulin. This lack of crossreactivity is not surprising since the antiserum was obtained from an immunized rabbit. When this IgG was added to cultured human umbilical vein endothelial cells and then removed and protein $C$ activation was measured subsequently (see Methods for details) (9), we found $90 \%$ inhibition of the rate obtained using control IgG.

Human lung thrombomodulin. We prepared thrombomodulin from a small sample of human lung as described in Methods in order to evaluate the possibility that the lack of

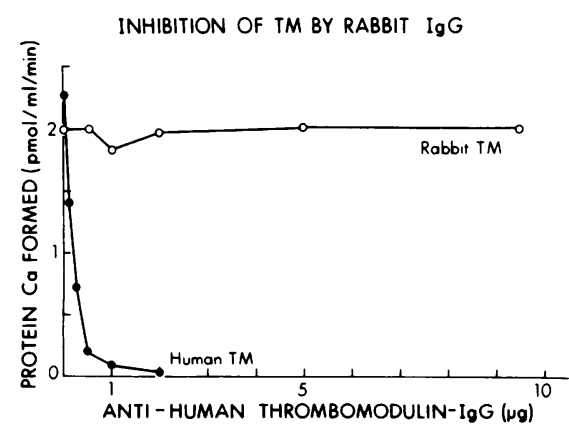

Figure 4. Inhibition of human or rabbit thrombomodulin by antihuman thrombomodulin rabbit IgG. Human or rabbit thrombomodulin (TM) $(0.05 \mathrm{pmol})$ was incubated with $0-10 \mu \mathrm{g}$ polyclonal anti-human thrombomodulin rabbit IgG for $15 \mathrm{~min}$ at $37^{\circ} \mathrm{C}$. The cofactor activity of thrombomodulin in protein $\mathrm{C}$ activation was assayed as described in Methods. In control experiments it was shown that the anti-thrombomodulin IgG does not interfere with protein $\mathrm{Ca}$. 
efficient inhibition of thrombin reactions by placental thrombomodulin reflected its tissue origin rather than a difference between humans and rabbits. We obtained approximately 50 $\mu \mathrm{g}$ of thrombomodulin from $7 \mathrm{~g}$ of lung based upon its protein $\mathrm{C}$ cofactor activity. SDS-polyacrylamide gel electrophoresis of the eluted material in the presence of 2-mercaptoethanol showed the major protein band at $M_{\mathrm{r}}=105,000$ (data not shown). An immunoblot of human lung thrombomodulin is shown in Fig. 5. The lung thrombomodulin co-migrates with placental thrombomodulin which was shown previously to migrate the same as rabbit lung thrombomodulin. The concentration of lung thrombomodulin was estimated by its activity in stimulating protein $\mathrm{C}$ activation compared to placental thrombomodulin assuming that both have the same activity. The immunoblot indicates that this assumption is valid since similar amounts of protein $\mathrm{C}$ activating activity give similar intensity by immunoblot (i.e., lane 1 vs. lanes 3 and 4). Thus thrombomodulin from lung and placenta have similar size, immunologic activity and protein $\mathrm{C}$ activating cofactor activity. We then tested the activity of human lung thrombomodulin to inhibit thrombin-induced serotonin release

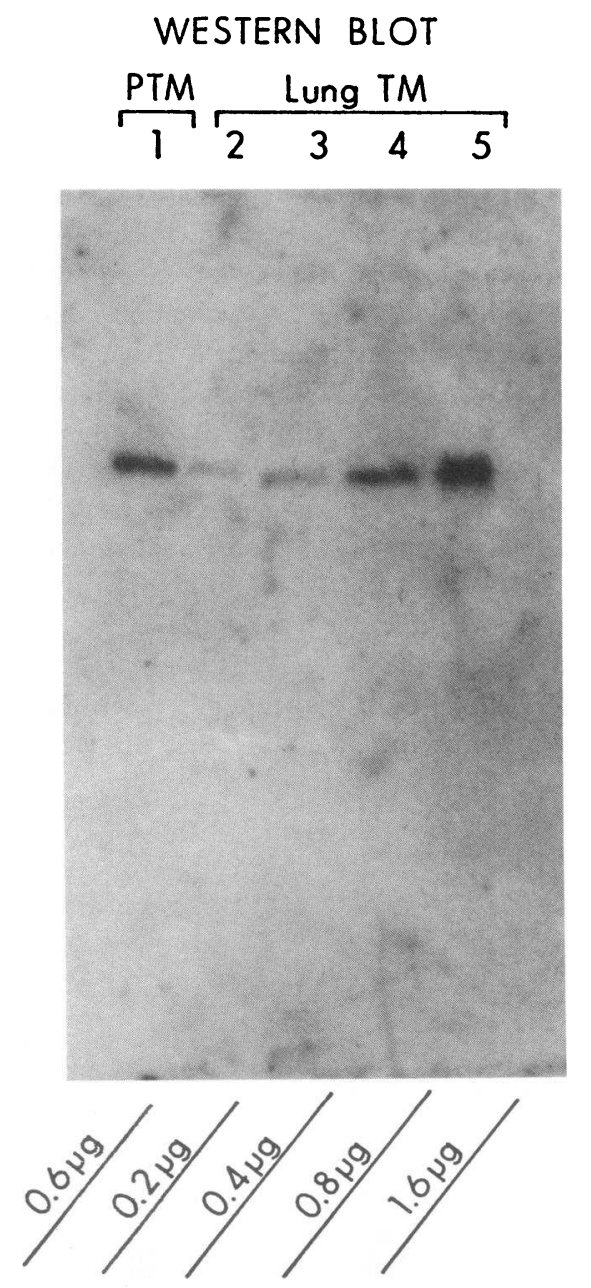

Figure 5. Immunoblot of thrombomodulin from placenta and lung. The immunoblot was performed as described in Methods. Isolated placental thrombomodulin $(0.6 \mu \mathrm{g})$, lane 1 ; immunoaffinity-purified human lung thrombomodulin, lanes 2-5. Lane 2, $0.2 \mu \mathrm{g}$; lane 3, 0.4 $\mu \mathrm{g}$; lane 4, $0.8 \mu \mathrm{g}$; lane 5, $1.6 \mu \mathrm{g}$. The activity of lung thrombomodulin was estimated from its protein $\mathrm{C}$ activating cofactor activity assuming that it is the same as placental thrombomodulin. in an experiment like that shown in Fig. 3. Lung thrombomodulin inhibited serotonin release by $0.1 \mathrm{nM}$ human thrombin in cacodylate buffers by $10 \%$ at $6 \mathrm{nM}$ and by $50 \%$ at $18 \mathrm{nM}$, compared to $50 \%$ inhibition by $0.4 \mathrm{nM}$ rabbit lung thrombomodulin and $80 \%$ by $2 \mathrm{nM}$ rabbit lung thrombomodulin. Thus we conclude that the lack of efficient inhibition of thrombin is a property of human thrombomodulin that is not unique to that derived from placenta.

\section{Discussion}

Thrombomodulin from rabbit lung has been previously shown to inhibit the procoagulant action of thrombin on fibrinogen (6), Factor V (6), and platelets (7). The ability of thrombomodulin to block thrombin procoagulant action in these three reactions is not the same. Thus only a slight excess of rabbit thrombomodulin over thrombin (1.6:1 in Fig. 1) completely blocks fibrinogen clotting. However, a ratio of rabbit thrombomodulin/thrombin of $20: 1$ is required to give $50 \%$ inhibition of Factor $\mathrm{V}$ activation and thrombin-induced serotonin release is blocked $\sim 50 \%$ at a ratio of $5: 1$. These differences in the ability of rabbit thrombomodulin to inhibit the procoagulant actions of thrombin probably result either from different relative affinities of thrombin for thrombomodulin vs. those for the procoagulant substrates or from different activities of the thrombin-thrombomodulin complex toward these other substrates. Human thrombomodulin is much less efficient in blocking the procoagulant actions of thrombin than the rabbit protein. It is $\mathbf{3 0}$ times less active in blocking fibrinogen clotting, barely inhibits Factor $\mathrm{V}$ activation, and only inhibits serotonin release from platelets by $50 \%$ at a ratio of thrombomodulin to thrombin of $>60: 1$. Thus, while thrombomodulin in humans is a potent cofactor in protein $\mathrm{C}$ activation it does not appear to block thrombin procoagulant reactions efficiently. An antigenic difference between the two proteins was observed using an anti-human thrombomodulin antiserum obtained from rabbits. This antibody is a potent inhibitor of human but not rabbit thrombomodulin. This antibody is directed against the endothelial cell moiety previously characterized as human thrombomodulin (1) from the finding that the antibody is able to block protein $\mathrm{C}$ activating cofactor activity on human umbilical vein endothelial cells. Since thrombomodulin is normally present as a membrane protein on endothelial cells and not in a solubilized detergent solution as used in this study, it is possible that different results might apply in vivo. Given this reservation, the current study implies that the binding of thrombin to thrombomodulin changes its specificity with respect to protein $C$ activation greatly compared to the minor effects observed on thrombin-catalyzed procoagulant reactions.

\section{Acknowledgments}

The authors thank Drs. Naomi and C. T. Esmon for providing the rabbit thrombomodulin used in this study.

This research was supported by grants HLBI-14147 (Specialized Center for Research in Thrombosis) and HL 16634 from the National Institutes of Health.

\section{References}

1. Esmon, C. T., and W. G. Owen. 1981. Identification of an endothelial cell cofactor for thrombin-catalyzed activation of protein C. Proc. Natl. Acad. Sci. USA. 78:2249-2252. 
2. Esmon, N. L., W. G. Owen, and C. T. Esmon. 1982. Isolation of a membrane-bound cofactor for thrombin-catalyzed activation of protein C. J. Biol. Chem. 257:859-864.

3. Walker, F. J., P. W. Sexton, and C. T. Esmon. 1979. The inhibition of blood coagulation by activated protein $\mathrm{C}$ through the selective inactivation of activated factor V. Biochim. Biophys. Acta. 571:333-342.

4. Suzuki, K., J. Stenflo, B. Dahlback, and G. Teodorsson. 1983. Inactivation of human coagulation factor $\mathrm{V}$ by activated protein $\mathrm{C}$. $J$. Biol. Chem. 258:1914-1920.

5. Vehar, G. A., and E. W. Davie. 1980. Preparation and properties of bovine factor VIII (antihemophilic factor). Biochemistry. 19:401409.

6. Esmon, C. T., N. L. Esmon, and K. W. Harris. 1982. Complex formation between thrombin and thrombomodulin inhibits both thrombin-catalyzed fibrin formation and factor $\mathrm{V}$ activation. J. Biol Chem. 257:7944-7947.

7. Esmon, N. L., R. C. Carroll, and C. T. Esmon. 1983. Thrombomodulin blocks the ability of thrombin to activate platelets. J. Biol. Chem. 258:12238-12242.

8. Salem, H. H., I. Maruyama, H. Ishii, and P. W. Majerus. 1984 Isolation and characterization of thrombomodulin from human placenta. J. Biol. Chem. 259:12246-12251.

9. Maruyama, I., H. H. Salem, and P. W. Majerus. 1984. Coagulation factor Va binds to human umbilical vein endothelial cells and accelerates protein C activation. J. Clin. Invest. 74:224-230.

10. Salem, H. H., N. L. Esmon, C. T. Esmon, and P. W. Majerus 1984. Effects of thrombomodulin and coagulation factor Va-light chain on protein C activation in vitro. J. Clin. Invest. 73:968-972.
11. Kane, W. H., and P. W. Majerus. 1981. Purification and characterization of human coagulation factor V. J. Biol. Chem. 256: 1002-1007.

12. Miletich, J. P., C. M. Jackson, and P. W. Majerus. 1978. Properties of the factor Xa binding site on human platelets. J. Biol. Chem. 253:6908-6916.

13. Owen, W. G., C. T. Esmon, and C. M. Jackson. 1974. The conversion of prothrombin to thrombin. J. Biol. Chem. 249:594-605.

14. Miletich, J. P., D. W. Majerus, and P. W. Majerus. 1978. Patients with congenital factor $\mathrm{V}$ deficiency have decreased factor $\mathrm{Xa}$ binding sites on their platelets. J. Clin. Invest. 62:824-831.

15. Tollefsen, D. M., J. R. Feagler, and P. W. Majerus. 1974. The binding of thrombin to the surface of human platelets. J. Biol. Chem. 249:2646-2651.

16. Shuman, M. A., and P. W. Majerus. 1975. The perturbation of thrombin binding to human platelets by anions. J. Clin. Invest. 56: 945-950.

17. Wallace, R. W., T. S. Lynch, E. A. Tallant, and W. Y. Cheung. 1977. Purification and characterization of an inhibitor protein of brain adenylate cyclase and cyclic nucleotide phosphodiesterase. J. Biol. Chem. 254:377-382.

18. Laemmli, V. K. 1970. Cleavage of structural proteins during the assembly of the head of bacteriophage T4. Nature (Lond.). 227: 680-685.

19. Burnette, W. N. 1981. "Western blotting": Electrophoretic transfer of proteins from sodium dodecyl sulfate-polyacrylamide gels to unmodified nitrocellulose and radiographic detection with antibody and radioiodinated protein A. Anal. Biochem. 112:195-203. 